University of Nebraska - Lincoln

DigitalCommons@University of Nebraska - Lincoln

Faculty Publications from the Harold W. Manter Laboratory of Parasitology

1975

PREVALENCE AND POTENTIAL VECTORS OF Haemoproteus IN NEBRASKA MOURNING DOVES

Ellis C. Greiner

Memorial University of Newfoundland

Follow this and additional works at: https://digitalcommons.unl.edu/parasitologyfacpubs

Part of the Parasitology Commons

Greiner, Ellis C., "PREVALENCE AND POTENTIAL VECTORS OF Haemoproteus IN NEBRASKA MOURNING DOVES" (1975). Faculty Publications from the Harold W. Manter Laboratory of Parasitology. 651.

https://digitalcommons.unl.edu/parasitologyfacpubs/651

This Article is brought to you for free and open access by the Parasitology, Harold W. Manter Laboratory of at DigitalCommons@University of Nebraska - Lincoln. It has been accepted for inclusion in Faculty Publications from the Harold W. Manter Laboratory of Parasitology by an authorized administrator of DigitalCommons@University of Nebraska - Lincoln. 


\title{
PREVALENCE AND POTENTIAL VECTORS OF Haemoproteus IN NEBRASKA MOURNING DOVES ${ }^{\varpi}$
}

\author{
ELLIS C. GREINER, WHO International Reference Centre for Avian Malaria Parasites \\ and Dept. of Biology, Memorial University, St. John's, Newfoundland, Canada
}

\begin{abstract}
Three hundred and nine mourning doves (Zenaida macroura) from Lancaster County, Nebraska, were examined for species of Haemoproteus. Older doves possessed higher Haemoproteus prevalences than younger doves. Mean total prevalence for each dove age group was as follows: adults, $61 \% \mathrm{H}$. sacharovi and $83 \% \mathrm{H}$. maccallumi; immatures, $35 \% \mathrm{H}$. sacharovi and $42 \% \mathrm{H}$. maccallumi; and nestlings, $31 \% H$. sacharovi and $16 \% H$. maccallumi. Yearly prevalences were less variable in mature doves than in immature and nestling doves. No correlation between nestling and parent Haemoproteus infections were observed, but nestmates in 10 or 18 nests harbored equivalent infections. Stilbometopa podopostyla and Microlynchia pusilla (Hippoboscidae) were collected from Nebraska doves. Hippoboscidae were collected from doves of all ages from April to August. Dove baited fly traps yielded Culex tarsalis and $C$. pipiens in Nebraska and Culicoides haematopotus, $C$. crepuscularis, and Simulium aureum in Ames, Iowa.
\end{abstract}

\section{INTRODUCTION}

Age, seasonal, and yearly prevalences of haemosporidians have been studied in several bird species. ${ }^{13,14,18,10,21,20}$ All of these studies dealt with populations of one or two bird species, whereas other studies discussed blood parasite prevalence at the avian community level. ${ }^{4,5,23,27}$ Few of these studies examined aspects of maintenance of the parasite species involved. The present study examined prevalences and potential vectors of two closely related haemosporidians evolving within the same vertebrate host.

\section{MATERIALS AND METHODS}

Adult and immature mourning doves were trapped or shot during March through October, 1969 and 1970 in Lancaster County, Nebraska. Blood smears were made from all birds at the time of capture and mature doves were released.
All doves were examined for louse flies (Hippoboscidae). Immature doves (collected as free-flying doves in immature plumage) and nestlings (doves collected from nests at 10 to 12 days of age) were held in the laboratory for at least 40 days before being considered negative. Blood smears were made from nestlings and immatures twice a week. Dove nests were placed into plastic bags and stored at room temperature for at least a week before they were examined for arthropods.

Contingency table analysis of age and seasonal data were made by the method of Snedecor. ${ }^{34}$ Three seasons were established: Immigrating $=$ March-April; Breeding = May-August; and Emigrating $=$ September-October. These seasons were determined from concurrent dove nesting studies which indicated less than $8 \%$ of the observed nesting occurred prior to May or after August (Greiner, unpublished).

(1) Part of this work was based on a thesis submitted to the Graduate College of the University of Nebraska-Lincoln in partial fulfillment of the requirements for the Doctor of Philosophy degree. 
Fly traps (double funnels constructed of $3 \mathrm{~cm} \mathrm{X} 3 \mathrm{~cm}$ wood frame and covered with window screen) were normally baited with doves between 1600 and 1700 hours. Doves and flies were removed from the traps between 700 and 800 hours. Fly trapping was conducted from mid-May to late August.

Two methods were used in attempts to feed hippoboscids on uninfected doves. The dove's breast was plucked and an uncapped vial containing the louse fly was held against the bare skin. The second method consisted of placing the restricted dove and the fly in a small cage overnight. Plastic snap-cap vials with the bottoms replaced with gauze were used for transferring the flies.

A series of fly trapping trials was undertaken in Ames, Iowa. These were conducted during the evening, 2000-2300 hours, from early June through August,
1973. Doves were exposed for $20 \mathrm{~min}$ in small cages constructed of $1 \mathrm{~cm}$ mesh hardware cloth and then the caged dove was covered with a nylon chiffon covered cage. Approximately $20 \mathrm{~min}$ later, the cage was examined for the presence of flies. Collapsible stands supported the traps $60 \mathrm{~cm}$ above ground. Nestling doves were treated as above.

\section{RESULTS}

\section{Haemoproteus Prevalence}

A higher prevalence of Haemoproteus was observed in older doves than younger doves (Table 1). Prevalences of $H$. maccallumi Novy and MacNeal, 1904 and $H$. sacharovi Novy and MacNeil, 1904 were influenced by host age ( $p /<0.001$ for both species) during the breeding seasons of 1969 and 1970 .

TABLE 1. Percentage of mourning doves infected with Haemoproteus.*

\begin{tabular}{|c|c|c|c|c|c|c|c|c|c|}
\hline & \multicolumn{3}{|c|}{$\begin{array}{l}\text { Immigrating } \\
\text { Population }\end{array}$} & \multicolumn{3}{|c|}{$\begin{array}{l}\text { Breeding } \\
\text { Population }\end{array}$} & \multicolumn{3}{|c|}{$\begin{array}{l}\text { Emigrating } \\
\text { Population }\end{array}$} \\
\hline & $68^{* *}$ & 69 & 70 & 68 & 69 & 70 & 68 & 69 & 70 \\
\hline \multicolumn{10}{|l|}{ Mature Doves } \\
\hline H. sacharovi & 69 & 52 & 70 & 60 & 68 & 63 & 36 & - & \\
\hline H. maccallumi & 65 & 56 & 60 & 90 & 91 & 91 & 84 & - & 100 \\
\hline Mixed infections & 50 & 39 & 39 & 54 & 64 & 58 & 28 & - & 28 \\
\hline Negative & 17 & 30 & 9 & 3 & 4 & 3 & 8 & - & 0 \\
\hline Number of matures & 48 & 23 & 23 & 95 & 66 & 87 & 25 & 0 & $\overline{7}$ \\
\hline \multicolumn{10}{|l|}{ Immature Doves } \\
\hline H. sacharovi & & & & 33 & 53 & 33 & 18 & - & 一 \\
\hline H. maccallumi & & & & 25 & 74 & 54 & 36 & - & - \\
\hline Mixed infections & & & & 4 & 37 & 25 & 0 & - & - \\
\hline Negative & & & & 46 & 10 & 38 & 45 & - & - \\
\hline Number of immatures & & & & 48 & 19 & 24 & 11 & 0 & 0 \\
\hline \multicolumn{10}{|l|}{ Nestling Doves } \\
\hline H. sacharovi & & & & 60 & 0 & 36 & & & \\
\hline H. maccallumi & & & & 0 & 27 & 16 & & & \\
\hline Mixed infections & & & & 0 & 0 & 7 & & & \\
\hline Negative & & & & 40 & 73 & 56 & & & \\
\hline Number of nestlings & & & & 10 & 15 & 45 & & & \\
\hline
\end{tabular}

- A total of 309 doves were observed in this study, excluding the 1968 data.

**1968 data from Greiner, $1970(\mathrm{~N}=237)$. 
No correlation between parent and nestling infections was observed ('Tab!e 2 ), but in over one-half of the nests $(10 / 18)$, both nestmates were either negative or infected with the same species of Haemoproteus.

No statistical differences were observed among the 3 year prevalences (1968 data from Greiner ${ }^{15}$ ) of $\mathrm{H}$. maccallumni and $H$. sacharovi during the spring $(\mathrm{p} /<0.99$ and $<0.70$ respectively); in mature doves during the summer ( $\mathrm{p} /<0.50$ for both species); and in immature doves during the summer $(\mathrm{p} /<$ 0.30 and $\mathrm{p} /<0.20$ respectively). Haemoproteus sacharovi prevalence in nestlings was influenced by year $(p /<0.005)$, whereas $H$. maccallumi prevalence in nestlings bordered upon being independent of year $(p /<0.10)$.

Since no statistical differences were recognized among the yearly Haemoproteus prevalences in mature doves, seasonal data from 1969 and 1970 were combined. Haemoproteus maccallumi prevalences were not independent of season for spring and summer mature doves $(\mathrm{p} /<0.001)$. Prevalences of $H$. sacharovi in spring and summer mature doves were independent of season $(p /<$ 0.70 ). Too few doves were collected during the fall to make statistical analysis meaningful.

\section{Potential Vectors}

Mourning doves live-trapped from 1968 to 1970 yielded several Hippoboscidae. A single Microlynchia pusilla (Speiser) was collected from each of two immature doves and three mature doves on the following dates: May 11, 1968, April 30, 1970, May 1, 1970, and June 23, 1970. One living adult $M$. pusilla was recovered 8 days after nest collection from a grackle-like nest reused by a dove and was the only louse fly collected from 23 doves nests. Stilbometopa podopostyla Speiser was removed from a mature dove on May 28, 1970. At least four other louse flies were lost from mature doves caught on April 28, 1969, March 4, 1970, and May 7, 1970 and a nestling captured on August 3, 1970.

No hippoboscids were collected in dove baited fly tra's. The following species of Culcidae were collected in the

TABLE 2. Infections of Nestmates and Parents Collected with Nest.

\begin{tabular}{|c|c|c|c|c|c|c|}
\hline & \multicolumn{6}{|c|}{ Nestling Infection } \\
\hline & 总 & 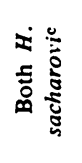 & 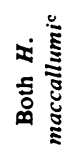 & 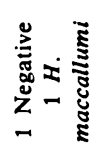 & 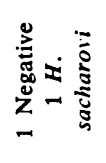 & 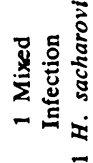 \\
\hline \multicolumn{7}{|c|}{$\begin{array}{l}\text { Number of nests containing } \\
2 \text { nestlings/nest. }\end{array}$} \\
\hline without adult & 5 & 2 & 2 & 3 & 2 & 1 \\
\hline with adult & $1^{\mathrm{a}}$ & 0 & 0 & $1^{b}$ & $1^{n}$ & 0 \\
\hline $\begin{array}{c}\text { Number of nests c } \\
1 \text { nestling/nest. } \\
\text { with adult }\end{array}$ & $1^{*}$ & $2^{2}$ & 0 & - & - & - \\
\hline
\end{tabular}

- Adult possessed $\boldsymbol{H}$. sacharovi and $\boldsymbol{H}$. maccallumi patent infections.

b Adult possessed $\boldsymbol{H}$. maccallumi patent infection only.

c Refers to the single infection in nests with only one nestling. 
baited traps: 522 Culex tarsalis Coquillet; 198 C. pipiens L.; one Orthopodomyia signifera (Coquille:); and one Aedes trivittatus Coquillet. Laboratory reared $C$. tarsalis females failed to feed on infected doves in three different experiments.

All doves from which hippoboscids were recovered harbored patent infections of at least one species of Haemoproteus. Efforts to use these flies to transmit Haemoproteus to uninfected immature doves did not produce patent infections by 29,61 , and 66 days for $M$. pusilla and 78 days for $S$. podopostyla. Two of the four flies placed upon the doves appeared to feed.

Both species of Haemoproteus and Leucocytozoon marchouxi Mathis and Leger, 1910 were present in dove nestlings on the Iowa study area. Engorged Culicoides crepuscularis Malloch and C. haemaproteus Malloch were recovered in small numbers from 12 June to 7 August. Several engorged Simulium aureum Fries were collected on 7 August.

\section{DISCUSSION}

\section{Haemoproteus Prevalence}

Occurrence of both $H$. maccallumi and $H$. sacharovi in nestling and immature mourning doves in Nebraska has been demonstrated. ${ }^{11,18}$ The higher prevalence in older doves may be explained by the fact that Adie $^{1}$ demonstrated pigeons can be reinfected with each bite of an infected fly. Furthermore, older doves have had a longer exposure to vectors and relapse has also been demonstrated for both species.

The lack of correlation between parent and nestling Haemoproteus infections indicated that the vector, once infected, does not move around to all inhabitants of the nest. If the vector were actually an ectoparasite, as a louse fly, one might expect to find all inhabitants of the nest infected with the same species of Haemoproteus. Possibly, if both adults could have been collected with the nest, there may have been a closer correlation between parent and nestling infections.
Significant differences were not found in the annual prevalences of Haemoprotcus in mature doves during the spring and summer or in the immature doves during the summer. This differs from that data of Hanson et al. ${ }^{19}$ which showed marked fluctuations in the annual adult and immature prevalences. During the two years in which they samp'ed more than 20 adults, the prevalences were nearly equal. Fewer than 10 adults were examined during the remaining 5 years of their study. Possibly a larger sample of adult doves would have reduced their variation. Immature dove samples of Hanson et al. ${ }^{19}$ were larger in size and annual variations agree with those of the present work. Annual ecological differences would contribute to the annual prevalence fluctuations due to vector population regulation by meteorological factors.

Seasonal Haemoproteus prevalence varies between years as does total Haemoproteus prevalence. Greiner ${ }^{18}$ found that $H$. sacharovi and $H$. maccallumi adult dove prevalences were influenced by season, whereas in the present study, total $H$. sacharovi prevalence was independent of season. This may be due to the lack of an adequate fall sample in the present study.

\section{Potential Vectors}

All proven vectors of columbiform infecting species of Haemoproteus have been louse flies. ${ }^{1,2,3,8,25,29,32}$ Few citations of natural hippoboscid infestations on mourning doves are present in the literature. Ornithoica confluenta and $O$. vicinia were collected from doves in Massachusetts. ${ }^{20,30}$ Bequaert ${ }^{7}$ recorded Lynchia americana from a dove in Alabama. Stilbometopa podopostyla was recovered from a Nebraska dove. ${ }^{10}$ Couch et. al. ${ }^{12}$ collected $19 \mathrm{M}$. pusilla from 13 of 106 doves and Brennan ${ }^{8}$ found up to $10 \mathrm{M}$. pusilla per dove and nearly all of 25-30 doves infested in Texas. Herman ${ }^{22}$ recovered $M$. pusilla from California doves. The two hippoboscid species collected in the present study, $S$. podopostyla and $M$. pusilla, are thought to utilize the mourning dove as a breeding host $^{i}$ and the other species are consi- 
dered to be accidental infestations. Bequaert $^{\circ}$ stated that some hippoboscids are capable of maintenance on abnormal hosts. Thus since flies are occasionally found on accidental hosts, a potential arises for interspecific vertebrate host inoculation with Haemoproteus sporozoites.

Lack of recorded hippoboscids from mourning dove nests ${ }^{24}$ is not surprising due to the loose construction of the dove nest. Since the $M$. pusilla which was collected from a nest, was obtained alive 8 days after nest collection, it probably originated from a puparium in the nest. This is the first record of an adult hippoboscid taken from an active mourning dove nest, thus suggesting that the mourning dove is in fact a breeding host for this fly.

The presence of $M$. pusilla and $S$. podopostyla on mourning doves demonstrates that Hippoboscidae are possib!e natural vectors of Haemoproteus. Hippoboscids were collected from doves of all ages from late April (when the first transmission to nestlings occurred) to August (when nestlings were still being infected). The lack of laboratory transmission of either species of Haemoproteus to uninfected doves by wild flies, and the small number of flies recovered may indicate some other arthropod may supplement hippoboscids in transmitting Haemoproteus to doves due to the high Haemoproteus prevalence found locally.

Biting midges (Ceratopogonidae) have been incriminated as vectors of noncolumbiform infecting species of Haemoproteus. ${ }^{4,15,10,28}$ Unfortunately, the potential of biting midges escaping from the funnel traps employed was not realized at the time of the Nebraska study. Thus the Iowa fly trapping trials were conducted to see if biting midges (Culicoides) were feeding upon doves in an area where dove Haemoproteus transmission occurred. Culicoides haematopotus and $C$. crepuscularis both were collected feeding upon doves during the time Haemoproteus was being transmitted to doves. These flies may be the primary vectors or at least supplementary vectors, assisting in the maintenance of the high Haemoproteus prevalence found in great plains doves. Simulium aureum is a potential vector of Leucocytozoon marchouxi.

Several authors have been unable to detect development of Hasmoprote'us beyond the ookinete stage in mosquitoes. ${ }^{16,17,31,33}$ Therefore, efforts to infect mosquitoes with Haemoproteus were not pursued, even though mosquitoes were repeatedly trapped.

\section{Acknowledgements}

I would like to acknowledge the guidance of Dr. John Janovy, Jr. throughout this study and to thank him for introducing me to avian malaria. My thanks also are extended to Dr. Wayne A. Rowley for his assistance with the Culicoides and to Dr. Gordon F. Bennett and Dr. Carlton M. Herman for their review of the manuscript.

\section{LITERATURE CITED}

1. ADIE, HELEN. 1924. The sporogony of Haemoproteus columbae. Bull. Soc. Path. Exot. 17: 605-612.

2. BAKER, J. R. 1966. Haemoproteus palumbis sp. nov. (Sporozoa, Haemosporina) of the English Wood-pigeon Columba p. palumbus. J. Protozool. 13: 515-519.

3. BAKER, J. R. 1968. The host restriction of Haemoproteus columbae. J. Protozool. 15: 334-335.

4. BENNETT, G. F. and A. M. FALLIS. 1960. Blood parasites of birds in Algonquin Park, Canada, and a discussion of their transmission. Can. J. Zool. 38: 261-273. 
5. BEAUDOIN, R. L., J. E. APPlegate, D. E. DAVIS and R. G. McLEAN. 1971. A model for the ecology of avian malaria. J. Wildl. Dis. 7: 5-13.

6. BEQUAERT, J. C. 1953. The Hippoboscidae or louse-flies (Diptera) of mammals and birds. Part 1. Structure, physiology, and natural history (continued). Ent. Am. 33: 211-442.

7. BEQUAERT, J. C. 1956. Taxonomy, evolution, and revision of American genera and species (concluded). Ent. Am. 36: 417-611.

8. BRENNAN, J. M. 1938. Additional records of Hippoboscidae from Mourning Doves. Science 88: 571.

9. COATNEY, G. R. 1933. Relapse and associated phenomena in the Haemoproteus infection of the pigeon. Am. J. Hyg. 18: 133-160.

10. COATNEY, G. R. 1938. Stilbometopa podopostyla (Hippoboscidae) from the Mourning Dove. Science 88: 258.

11. COATNEY, G. R. and E. WEST. 1940. Studies on Haemoproteus sacharovi of Mourning Doves and Pigeons, with notes on $\mathrm{H}$. maccallumi. Am. J. Hyg. 31: 9-14.

12. COUCH, A. B. Jr., B. GRABSTALD and K. J. KIMBROUGH. 1961. Collecting louse-flies from Mourning Doves. J. Wildl. Mgmt 25: 440-442.

13. DORNEY, R. S. and A. C. TODD. 1960. Spring incidence of ruffed grouse blood parasites. J. Parasit. 46: 687-694.

14. FALLIS, A. M. 1945. Population trends and blood parasites of ruffed grouse in Ontario. J. Wildl. Mgmt 9: 203-206.

15. FALLIS, A. M. and G. F. BENNETT. 1961. Sporogony of Leucocytozoon and Haemoproteus in Simuliids and Ceratopogonids and a revised classification of the Haemosporidiida. Can. J. Zool. 39: 215-228.

16. FALliS, A. M. and D. M. WOOD. 1957. Biting midges (Diptera: Ceratopogonidae) as intermediate hosts for Haemoproteus of ducks. Can. J. Zool. 35: $425-435$.

17. FARMER, J. N. 1962. Relapse of Haemoproteus sacharovi infections in Mourning Doves. Trans. N. Am. Wildl. and Nat. Res. Conf. 27: 164-174.

18. GREINER, E. C. 1970. Epizootiological studies on Haemoproteus in Nebraska Mourning Doves (Zenaidura macroura). J. Parasit. 56: 187-188.

19. HANSON, H. C., N. D. LEVINE, C. W. KOSSACK, S. KANTOR and L. J. STANNARD. 1957. Parasites of the Mourning Dove (Zenaidura macroura carolinensis) in Illinois. J. Parasit. 43: 186-193.

20. HERMAN, C. M. 1937. Notes on hippoboscid flies. Bird Banding 8: 161-166.

21. HERMAN, C. M. 1938. Epidemiology of malaria in eastern redwings Agelaius p. phoeniceus. Am. J. Hyg. 28: 232-243.

22. HERMAN, C. M. 1945. Hippoboscid flies as parasites of game animals in California. California Fish and Game 31: 16-25.

23. HERMAN, C. M., W. C. REEVES, H. E. MCCLURE, E. M. FRENCH and W. MCD. HAMMOND. 1954. Studies on avian malaria in vectors and hosts of encephalitis in Kern County, California. Am. J. trop. Med. Hyg. 3: 676-695.

24. HICKS, E. A. 1959. Occurrence of Insects in Birds' Nests. Iowa College Press, Ames.

25. HUFF, C. G. 1932. Studies on Haemoproteus of Mourning Doves. Am. J. Hyg. 16: 618-623.

26. JANOVY, J., Jr. 1966. Epidemiology of Plasmodium hexamerium Huff, 1935, in Meadowlarks and Starlings of the Cheyenne Bottoms, Barton County, Kansas. J. Parasit. 52: 573-578. 
27. JORDAN, HELEN B. 1943. Blood Protozoa of birds trapped at Athens, Georgia. J. Parasit. 29: 250-263.

28. KHAN, R. A. and A. M. FALLIS. 1971. A note on the sporogony of Parahaemoproteus velans (=Haemoproteus velans Coatney and Roudabush) (Haemosporidia: Haemoproteidae) in species of Culicoides. Can. J. Zool. 49: 420-421.

29. KLEI, T. R., D. L. DeGIUSTI and P. R. J. HERATH. 1968. Field and laboratory studies of Haemoproteus columbae and its vector Pseudolynchia canariensis in the pigeon poplation of Detroit, Michigan. Am. Zool. 8: 823.

30. MAIN, A. J. and K. S. ANDERSON. 1970. The genera Ornithoica, Ornithomya, and Ornithoctona in Massachusetts (Diptera: Hippoboscidae). Bird Banding 41: 300-306.

31. MEZINCESCU, D. 1909. Evolution des ookinetes d'Haemoproteus dans l'intestin des moutiques. C. R. Soc. Biol., Paris 66: 329-330.

32. SERGENT, ED. and ET. SERGENT. 1906. Sur le second hôte de l'Haemoproteus (Halteriaïum) du pigeon. C.R. Soc. Biol., Paris 61: 494-496.

33. SINGH, J., C. P. NAIR and A. DAVID. 1951. Five years observation on the incidence of blood Protozoa in house sparrows (Passer domesticus L.) and in pigeons (Columba livia Gmelin) in Delhi. Ind. J. Malariol. 5: 229-233.

34. SNEDECOR, G. W. 1956. Statistical Methods Applied to Experiments in Agriculture and Biology. Iowa State College Press, Ames. 